\title{
Studies on the Novel Antiallergic Agent HSR-609: Its Penetration into the Central Nervous System in Mice and Guinea Pigs and Its Selectivity for the Histamine $\mathrm{H}_{1}$-Receptor
}

\author{
Masato Kakiuchi, Tetsuo Ohashi, Keiichi Musoh, Kimio Kawamura, Kouji Morikawa and Hideo Kato \\ Research and Development Division, Hokuriku Seiyaku Co., Ltd., 37-1-1 Inokuchi, Katsuyama, Fukui 911, Japan
}

Received July 26, $1996 \quad$ Accepted January 17, 1997

\begin{abstract}
We studied the pharmacological characteristics of HSR-609 (3-[4-(8-fluoro-5,11-dihydrobenz $[b]$ oxepino[4,3-b]pyridin-11-ylidene)-piperidino]propionic acid dihydrate), a novel amphoteric antiallergic agent, on the central nervous system (CNS). Its selectivity for the histamine $\mathrm{H}_{1}$-receptor and its ability to penetrate into the CNS were compared with those of typical antiallergic agents and the nonamphoteric basic compound PY-608 (8-fluoro-5,11-dihydro-11-(1-methyl-4-piperidylidene)benz[b]oxepino[4,3-b]pyridine), which has a chemical structure similar to that of HSR-609. In the in vitro study, HSR-609 had a high affinity for $\mathrm{H}_{1}$-receptors in the guinea pig cerebral cortex in comparison to affinities for muscarinic and serotonin 5- $\mathrm{HT}_{2}$-receptors in the rat cerebral cortex, while the selectivity of PY-608 for the $\mathrm{H}_{1^{-}}$ receptor was low. The inhibitory effects of these antiallergic agents on histamine-induced increase of vascular permeability in mice $\left(\mathrm{ED}_{s_{0}}\right)$ were compared with the displacement of $\left[{ }^{3} \mathrm{H}\right]$ mepyramine binding to $\mathbf{H}_{1^{-}}$ receptors in mouse brain ex vivo (ID $\left(\mathrm{D}_{50}\right)$. The $\mathrm{ID}_{50} / \mathrm{ED}_{50}$ ratio of HSR-609 was much larger than those of cyproheptadine, ketotifen and PY-608 and larger than those of terfenadine and cetirizine. HSR-609 was found to display selective displacement of the $\left[{ }^{3} \mathrm{H}\right]$ mepyramine binding to $\mathrm{H}_{1}$-receptors for lung vs cerebral cortex as found with terfenadine in guinea pigs ex vivo. These findings suggest that HSR- 609 has high selectivity for the $\mathrm{H}_{1}$-receptor and poor ability to penetrate into the CNS in mice and guinea pigs due to its amphoteric chemical structure.
\end{abstract}

Keywords: Antiallergic agent, HSR-609, Central nervous system penetration, Histamine $\mathrm{H}_{1}$-receptor, Amphoteric compound

We have synthesized many amphoteric compounds through zwitter-ionization of classical tricyclic antihistamines by conversion of $\mathrm{N}$-alkyl groups into $\mathrm{N}$-alkylenecarboxy groups to develop non-sedative antiallergic agents with potent antihistaminic activities and have investigated the potencies of the antiallergic effects of these compounds as well as their depressant effects on the central nervous system (CNS) $(1,2)$. These studies showed that the combination of zwitter-ionization and introduction of a pyridine component into the tricyclic antihistamines was important for attaining higher hydrophilicity, which was considered to be a factor in reducing penetration into the CNS (2). Our efforts finally led to a new amphoteric compound HSR-609 (3-[4-(8fluoro-5,11-dihydrobenz[b]oxepino[4,3-b]pyridin-11-ylidene)piperidinolpropionic acid dihydrate) (2) (Fig. 1). Various pharmacological studies on mice, rats, guinea pigs and dogs have shown that HSR-609 has potent anti- allergic and antihistaminic activities in vivo $(2,3)$. The ability of HSR -609 to penetrate into the CNS was much lower than that of ketotifen fumarate as determined by the ex vivo displacement of $\left[{ }^{3} \mathrm{H}\right]$ mepyramine binding to histamine $\mathrm{H}_{1}$-receptors in the mouse brain in comparison with its peripheral antihistaminic effect (2). However, the $\mathrm{H}_{1}$-receptor selectivity of HSR-609 in comparison to other receptors is yet to be evaluated, and the CNS penetrative ability of HSR -609 has not yet been compared with those of other typical antiallergic agents nor among species other than mice. Therefore, to further elucidate the pharmacological profile of HSR-609, we compared it with typical sedative antiallergic agents, cyproheptadine hydrochloride, ketotifen fumarate, azelastine hydrochloride and oxatomide, and also with typical non-sedative antiallergic agents, terfenadine and cetirizine dihydrochloride (4-11). The selectivity of HSR-609 for the $\mathrm{H}_{1}$-receptor was investigated by in vitro $\mathrm{H}_{1}$-receptor 


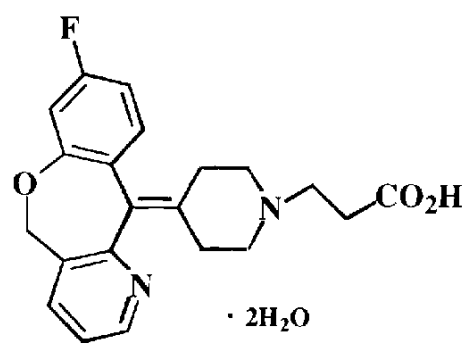

HSR-609

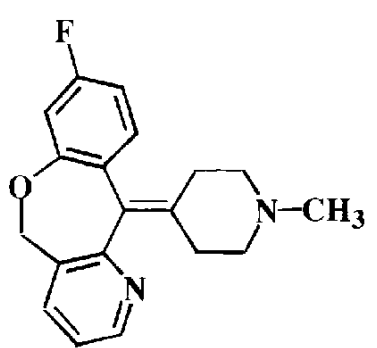

PY-608

Fig. 1. Chemical structures of HSR-609 and PY-608.

binding in guinea pig cerebral cortex and muscarinic and serotonin $5-\mathrm{HT}_{2}$-receptor bindings in rat cerebral cortex. The ability to penetrate into the CNS in mice was evaluated from the inhibitory effect on histamine-induced increase of peripheral vascular permeability in comparison to the ex vivo displacement of $\left[{ }^{3} \mathrm{H}\right]$ mepyramine binding to brain $\mathrm{H}_{1}$-receptors. For guinea pigs, the penetrative ability was evaluated by the ex vivo displacement of $\left[{ }^{3} \mathrm{H}\right]$ mepyramine binding to $\mathbf{H}_{1}$-receptors in the cerebral cortex and the lung, one of the peripheral target organs of antiallergic agents. We also tried to elucidate whether the amphoteric chemical structure of HSR-609 is related to its selectivity for the $\mathrm{H}_{1}$-receptor and its ability to penetrate into the CNS by comparing its properties with those of the non-amphoteric basic compound PY-608 (8-fluoro5,11-dihydro-11-(1-methyl-4-piperidylidene)benz [b]oxepino[4,3-b]pyridine), which has a chemical structure similar to that of HSR-609 (Fig. 1).

\section{MATERIALS AND METHODS}

\section{Animals}

Male ICR mice (Charles River Japan, Kanagawa), male Wistar rats (Japan SLC, Shizuoka) and male Hartley guinea pigs (Japan SLC) were used. The animals were fasted for more than $16 \mathrm{hr}$ before oral administration of the test compounds.

\section{Effect on in vitro binding assay of $H_{1}$-receptors}

The in vitro binding assay of $\mathrm{H}_{1}$-receptors was performed using the guinea pig cerebral cortex. Guinea pigs (6-week-old) were killed by decapitation, and the cerebral cortex was rapidly removed and homogenized by a Polytron (Kinematica, Luzern, Switzerland) in 20 vol. of ice-cold $50 \mathrm{mM}$ sodium-potassium phosphate buffer ( $\mathrm{pH}$ 7.4). The homogenate was centrifuged 2 times at $50,000 \times \mathrm{g}$ for $15 \mathrm{~min}$ at $4^{\circ} \mathrm{C}$ using an ultracentrifuge (70P-72; Hitachi, Tokyo). The final membrane pellet was resuspended in $50 \mathrm{vol}$. of the ice-cold buffer. The receptor-ligand binding assay was performed with $\left[{ }^{3} \mathrm{H}\right]$ mepyramine (final concentration of $2 \mathrm{nM}$ ) in duplicate according to the methods of Ahn and Barnett (12) with some modifications. The binding reaction was initiated by mixing the buffer with test compound $(0.4 \mathrm{ml})$, the radioligand $(0.1 \mathrm{ml})$ and the final pellet suspension for each receptor $(0.5 \mathrm{ml})$. The mixture was incubated with shaking at $25^{\circ} \mathrm{C}$ for $120 \mathrm{~min}$. The incubation was terminated by adding $5 \mathrm{ml}$ of ice-cold buffer, and the sample was rapidly filtered through a Whatman GF/B glass filter using a Cell Harvester (M-24R; Brandel, Geithersburg, MD, USA) and then washed 3 times with $5 \mathrm{ml}$ of ice-cold buffer. The filters were dried and placed in $7 \mathrm{ml}$ of Aquazol-2 (Dupont/NEN, Boston, MA, USA), and the radioactivity was measured with a liquid scintillation counter (1600TR; Packard, Meriden, CT, USA). The specific binding of radioligand was taken as the difference between the radioactivity bound in the absence or presence of $1 \mu \mathrm{M}$ promethazine hydrochloride. The $\mathrm{IC}_{50}$ values (concentrations of test compounds producing $50 \%$ inhibition of specific binding of radioligand) were determined according to the EBDA ligand program (13). The $K_{d}$ (dissociation constant) values were calculated from Scatchard plots. The radioligand competition activities of test compounds were expressed as $\mathrm{K}_{\mathrm{i}}=\mathrm{IC}_{50} /\left(1+\mathrm{L} / \mathrm{K}_{\mathrm{d}}\right)$, where $\mathbf{L}$ was the concentration of the radioligand used (14). Negative logarithms of $K_{i}\left(\mathrm{pK}_{\mathrm{i}}\right)$ values of the test compounds were determined.

\section{Effect on in vitro binding assay of muscarinic and 5-} $H T_{2}$-receptors

In vitro binding assays of muscarinic and $5-\mathrm{HT}_{2}$-receptors were performed using the rat cerebral cortex. Rats (6- to 10-week-old) were killed by decapitation and the cerebral cortex was rapidly removed and homogenized in $20 \mathrm{vol}$. of ice-cold buffer (for muscarinic receptor binding: $50 \mathrm{mM}$ sodium-potassium phosphate buffer, $\mathrm{pH} 7.4$; for 5- $\mathrm{HT}_{2}$-receptor binding: $50 \mathrm{mM}$ Tris-hydrochloride buffer, $\mathrm{pH}$ 7.4). The homogenate was centrifuged 2 times 
at $50,000 \times \mathrm{g}$ for $15 \mathrm{~min}$ at $4^{\circ} \mathrm{C}$. The final membrane pellet was resuspended in 1200 vol. of ice-cold buffer for muscarinic receptor binding and in 100 vol. for $5-\mathrm{HT}_{2}$-receptor binding. The receptor-ligand binding assays were performed in duplicate by the method of Oshita et al. (15) using $\left[{ }^{3} \mathrm{H}\right]$ quinuclidinyl benzilate (final concentration of $0.03 \mathrm{nM}$ ) for muscarinic receptor binding and by the method of Leysen et al. (16) with some modifications using $\left[{ }^{3} \mathrm{H}\right]$ ketanserin (final concentration of $0.4 \mathrm{nM}$ ) for 5- $\mathrm{HT}_{2}$-receptor binding. The receptor-ligand binding reaction was initiated by mixing the buffer with test compound $(3.4 \mathrm{ml}$ for muscarinic receptor binding or $0.4 \mathrm{ml}$ for $5-\mathrm{HT}_{2}$-receptor binding), the radioligand $(0.1 \mathrm{ml})$ and the final pellet suspension for each receptor $(0.5 \mathrm{ml})$. The mixture was incubated with shaking at $37^{\circ} \mathrm{C}$ for $60 \mathrm{~min}$ for muscarinic receptor binding or at $37^{\circ} \mathrm{C}$ for $15 \mathrm{~min}$ for

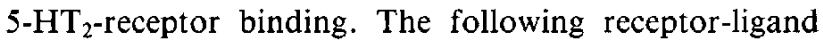
binding assays were carried out according to the abovedescribed procedure for the in vitro binding assay of $\mathrm{H}_{1}$ receptors. The specific binding of radioligand was taken as the difference between the radioactivity bound in the absence or presence of $1 \mu \mathrm{M}$ atropine sulfate monohydrate for muscarinic receptor binding or $1 \mu \mathrm{M}$ mianserin hydrochloride for $5-\mathrm{HT}_{2}$-receptor binding.

\section{Effect on histamine-induced vascular increase of perme-} ability in mice

The test compounds were orally administered to 6week-old mice in groups of 7-13 animals. After $1 \mathrm{hr}$, the mice were lightly anesthetized with ether. Immediately following an intravenous injection of $0.2 \mathrm{ml}$ of $1 \%$ Evans blue saline solution through the caudal vein, a cutaneous reaction was induced by intradermal injection of 25 $\mu \mathrm{l} / \mathrm{site}$ of histamine dihydrochloride $(0.1 \mathrm{mg} / \mathrm{ml})$ into the depilated skin on the back. After $30 \mathrm{~min}$, the mice were killed by cervical dislocation, the histamine injection site was isolated, and the intensity of the response was evaluated by the amount of extravasated dye according to the method of Katayama et al. (17). The percentage of inhibition of the test compound was calculated by comparison with the mean responses of vehicle controls, while the $\mathrm{ED}_{50}$ values (doses of test compounds producing $50 \%$ inhibition of histamine-induced vascular permeability) and their $\mathbf{9 5 \%}$ confidence limits were calculated from the number of animals showing more than $50 \%$ inhibition at each dose according to the Probit method of the Yukms Statistical Library (Yukms, Tokyo).

Effect on ex vivo $\left[^{3} H\right]$ mepyramine binding to $H_{I}$-receptors in the mouse brain

The test compounds were orally administered to 6week-old mice in groups of 5 animals each. After $1 \mathrm{hr}$, the mice were killed by cervical dislocation, and the whole brains were immediately removed and homogenized in $40 \mathrm{vol}$. of ice-cold $50 \mathrm{mM}$ sodium-potassium phosphate buffer ( $\mathrm{pH}$ 7.4). The receptor-ligand binding assay was performed in duplicate using $\left[{ }^{3} \mathrm{H}\right]$ mepyramine (final concentration of $2 \mathrm{nM}$ ) by the method of Ahn and Barnett (12) with some minor modifications. The binding reaction was initiated by mixing the buffer $(0.4 \mathrm{ml})$, the radioligand $(0.1 \mathrm{ml})$ and the brain homogenate suspension $(0.5 \mathrm{ml})$. The mixture was incubated at $25^{\circ} \mathrm{C}$ for $30 \mathrm{~min}$ with shaking. The following receptor-ligand binding assays were carried out by the above-described in vitro binding assay of $\mathrm{H}_{1}$-receptors. The $\mathrm{ID}_{50}$ values (doses of test compounds producing $50 \%$ inhibition of the specific binding of a radioligand) and their $95 \%$ confidence limits were calculated from the percentage of inhibition at each dose according to the method of Tallarida and Murray (18).

Effect on ex vivo ${ }^{3} \mathrm{H} / \mathrm{mepyramine}$ binding to $\mathrm{H}_{1}$-receptors in the cerebral cortex and the lung of guinea pigs

The test compounds were orally administered to 5- to 6-week-old guinea pigs in groups of 4 animals each. After $2 \mathrm{hr}$, the guinea pigs were killed by decapitation, and the cerebral cortex and the lung parenchyma were immediately removed and homogenized in $10 \mathrm{vol}$. of ice-cold $50 \mathrm{mM}$ sodium-potassium phosphate buffer $(\mathrm{pH}$ 7.4). The lung homogenate was filtered through two layers of gauze. The homogenates were centrifuged 2 times at $50,000 \times g$ for $15 \mathrm{~min}$ at $4{ }^{\circ} \mathrm{C}$. The final membrane pellets were resuspended in $50 \mathrm{vol}$. of ice-cold buffer in the case of the cerebral cortex pellets or in $40 \mathrm{vol}$. of ice-cold buffer in the case of the lung pellets. The following receptor-ligand binding assay of ex vivo displacement of $\left[{ }^{3} \mathrm{H}\right]$ mepyramine binding was carried out in triplicate as described in the above method for the ex vivo $\left[{ }^{3} \mathrm{H}\right]$ mepyramine binding to $\mathbf{H}_{1}$-receptors in the mouse brain

\section{Drugs}

The following agents were purchased: cyproheptadine (cyproheptadine hydrochloride; Pharmaceutia, Milan, Italy); ketotifen (ketotifen fumarate; Orion Chemicals, Espoo, Finland); terfenadine and mianserin hydrochloride (Sigma Chemical, St. Louis, MO, USA); ether anesthetic (Showa Ether, Tokyo); histamine dihydrochloride (Nacalai Tesque, Kyoto); Evans blue, promethazine hydrochloride and atropine sulfate monohydrate (Wako Pure Chemical Industries, Osaka); and [ $\left.{ }^{3} \mathrm{H}\right]-$ mepyramine, $\left[{ }^{3} \mathrm{H}\right]$ quinuclidinyl benzilate and $\left[{ }^{3} \mathrm{H}\right]$ ketanserin (Dupont/NEN, Boston, MA, USA). HSR-609, PY608 , azelastine (azelastine hydrochloride), oxatomide and cetirizine (cetirizine dihydrochloride) were synthesized at the Research and Development Division, Hokuriku Seiyaku Co., Ltd. The orally administered test compounds, HSR-609, PY-608, cyproheptadine, oxatomide, 
terfenadine and cetirizine, were suspended in $5 \%$ gum arabic, while azelastine and ketotifen were dissolved in distilled water. In the in vitro experiment, HSR-609, ketotifen, azelastine and cetirizine were dissolved in distilled water; PY-608 and oxatomide were dissolved in $0.1 \mathrm{~N} \mathrm{HCl}$; and cyproheptadine and terfenadine were dissolved in ethanol. All these dissolved compounds were diluted with each assay buffer.

\section{Statistical analyses}

All data are expressed as means \pm S.E. Statistical analyses were carried out using the Yukms Statistical Library. Statistical differences among multiple groups were determined by Dunnett's multiple comparison test. $P$ values less than 0.05 were considered statistically significant.

\section{RESULTS}

Effect on in vitro binding assay of $\mathrm{H}_{1}-$, muscarinic and 5 $H T_{2}$-receptors

With respect to the $\mathrm{H}_{1}$-receptor binding in the guinea pig cerebral cortex in vitro, HSR-609, PY-608 and typical antiallergic agents concentration-dependently inhibited the $\left[{ }^{3} \mathrm{H}\right]$ mepyramine binding to $\mathrm{H}_{1}$-receptors and displayed high affinities for $\mathrm{H}_{1}$-receptors $\left(\mathrm{pK}_{\mathrm{i}}>7\right)$. Among these compounds, PY-608, cyproheptadine, ketotifen and azelastine showed much higher affinities for $\mathrm{H}_{1}$ receptors $\left(\mathrm{pK}_{\mathrm{i}}>9\right)$ (Table 1).

As for the muscarinic receptor binding in the rat cerebral cortex in vitro, HSR-609 and cetirizine hardly affected the $\left[{ }^{3} \mathrm{H}\right]$ quinuclidinyl benzilate binding to the muscarinic receptors and had little affinity for these receptors $\left(\mathrm{pK}_{\mathrm{i}}<5\right)$. In contrast, PY-608 and cyprohepta- dine had high affinities for muscarinic receptors $\left(\mathrm{pK}_{\mathrm{i}}>7\right)$; ketotifen, azelastine and oxatomide also showed moderate affinities $\left(7>\mathrm{pK}_{\mathrm{i}}>6\right)$; and terfenadine displayed low affinity $\left(6>\mathrm{pK}_{\mathrm{i}}>5\right)$. The ratio of the $\mathrm{H}_{\mathrm{L}}$-receptor affinity to the muscarinic receptor affinity was calculated. The selectivity of HSR-609 for the $\mathrm{H}_{1}$-receptor was 690 , which was lower than those of ketotifen (1200), azelastine (1000) and cetirizine $(>2700$ ), but higher than those of PY-608 (25), cyproheptadine (3.3), oxatomide (17) and terfenadine (45) (Table 1).

With the 5- $\mathrm{HT}_{2}$-receptor binding in the rat cerebral cortex in vitro, HSR-609 and cetirizine hardly affected the $\left[{ }^{3} \mathrm{H}\right]$ ketanserin binding to 5 - $\mathrm{HT}_{2}$-receptors and had little affinity for $5-\mathrm{HT}_{2}$-receptors $\left(\mathrm{pK}_{\mathrm{i}}<5\right)$. In contrast, PY608 , cyproheptadine, ketotifen, azelastine and oxatomide had high affinities for 5 - $\mathrm{HT}_{2}$-receptors $\left(\mathrm{pK}_{\mathrm{i}}>7\right)$, while terfenadine displayed moderate affinity for $5-\mathrm{HT}_{2}$-receptors $\left(7>\mathrm{pK}_{\mathrm{i}}>6\right)$. The ratio between the $\mathrm{H}_{1}$-receptor affinity and the 5 - $\mathrm{HT}_{2}$-receptor affinity was calculated. The selectivity of HSR-609 for the $\mathrm{H}_{1}$-receptor was 250 , which was lower than that of cetirizine (740), similar to that of ketotifen (230), and higher than those of PY-608 (81), cyproheptadine (2.2), azelastine (110), oxatomide (0.49) and terfenadine (9.1) (Table 1).

\section{Effect on histamine-induced increase of vascular perme- ability in mice}

Extravasated dye was found at the injection site on the back with $2.5 \mu \mathrm{g}$ histamine. The amount of extravasated dye in the control ranged from $9.0 \pm 1.5$ to $14.7 \pm 1.3$ $\mu \mathrm{g} /$ site among the experiments. Oral administration of HSR-609 at doses of $0.01-0.1 \mathrm{mg} / \mathrm{kg}$ produced dosedependent inhibition of the histamine-induced increase of vascular permeability. The inhibition of HSR-609 at

Table 1. Inhibitory effects of HSR-609, PY-608 and typical antiallergic agents on histamine $\mathbf{H}_{1}$-receptor binding in guinea pig cerebral cortex and muscarinic and serotonin $5-\mathrm{HT}_{2}$-receptor bindings in rat cerebral cortex in vitro

\begin{tabular}{|c|c|c|c|c|c|}
\hline \multirow{3}{*}{ Radioligand } & Histamine $\mathrm{H}_{1}$ & Muscarinic & \multicolumn{3}{|c|}{ Serotonin $5-\mathrm{HT}_{2}$} \\
\hline & {$\left[{ }^{3} \mathrm{H}\right]$ mepyramine } & $\begin{array}{c}{\left[{ }^{3} \mathrm{H}\right] \text { quinuclidinyl }} \\
\text { benzilate }\end{array}$ & \multicolumn{3}{|c|}{$\left[{ }^{3} \mathrm{H}\right]$ ketanserin } \\
\hline & $\begin{array}{l}\mathrm{pK}_{\mathrm{i}} \\
{[\mathrm{A}]}\end{array}$ & $\begin{array}{l}\mathrm{pK}_{\mathrm{i}} \\
{[\mathrm{B}]}\end{array}$ & $\begin{array}{c}\text { Ratio } \\
\text { [Anti-log (A-B)] }\end{array}$ & $\begin{array}{l}\mathrm{pK}_{\mathrm{i}} \\
\text { [C] }\end{array}$ & $\begin{array}{c}\text { Ratio } \\
\text { [Anti-log (A-C)] }\end{array}$ \\
\hline HSR-609 & $7.31 \pm 0.06$ & $4.47 \pm 0.11$ & 690 & $4.92 \pm 0.02$ & 250 \\
\hline PY -608 & $9.28 \pm 0.04$ & $7.89 \pm 0.08$ & 25 & $7.37 \pm 0.10$ & 81 \\
\hline Cyproheptadine & $9.42 \pm 0.09$ & $8.90 \pm 0.08$ & 3.3 & $9.08 \pm 0.03$ & 2.2 \\
\hline Ketotifen & $9.78 \pm 0.08$ & $6.69 \pm 0.13$ & 1200 & $7.41 \pm 0.14$ & 230 \\
\hline Azelastine & $9.34 \pm 0.07$ & $6.34 \pm 0.01$ & 1000 & $7.31 \pm 0.03$ & 110 \\
\hline Oxatomide & $7.82 \pm 0.02$ & $6.58 \pm 0.01$ & 17 & $8.13 \pm 0.17$ & 0.49 \\
\hline Terfenadine & $7.21 \pm 0.03$ & $5.56 \pm 0.09$ & 45 & $6.25 \pm 0.09$ & 9.1 \\
\hline Cetirizine & $7.43 \pm 0.11$ & $<4$ & $>2700$ & $4.56 \pm 0.02$ & 740 \\
\hline
\end{tabular}

$\mathrm{pK}_{\mathrm{i}}\left(-\log \mathrm{K}_{\mathrm{i}}\right)$ values are expressed as the mean \pm S.E. values of $3-5$ experiments. $\mathrm{K}_{\mathrm{d}}$ values of the cerebral cortex membrane for $\mathrm{H}_{1^{-}}$, muscarinic and $5-\mathrm{HT}_{2}$-receptor binding were $400 \pm 38,16.2 \pm 1.2$ and $418 \pm 66 \mathrm{pM}$, respectively. 
Table 2. Comparison of the inhibitory effects of HSR-609, PY-608 and typical antiallergic agents on histamine-induced increase of vascular permeability in mice and $\left[{ }^{3} \mathrm{H}\right]$ mepyramine binding to histamine $\mathrm{H}_{1}$-receptors in mouse brain ex vivo

\begin{tabular}{|c|c|c|c|}
\hline & $\begin{array}{c}\text { Mouse } \\
\text { histamine-induced } \\
\text { increase of } \\
\text { vascular permeability }\end{array}$ & $\begin{array}{c}\text { Mouse brain } \\
\text { (ex vivo) } \\
\mathrm{H}_{1} \text {-receptor } \\
\text { binding }\end{array}$ & \\
\hline & $\begin{array}{c}\mathrm{ED}_{s_{0}}(95 \% \text { C.L. }) \\
{[\mathrm{A}]} \\
(\mathrm{mg} / \mathrm{kg}, \mathrm{p} . \mathrm{o})\end{array}$ & $\begin{array}{c}\mathrm{ID}_{50}(95 \% \text { C.L. }) \\
{[\mathrm{B}]} \\
(\mathrm{mg} / \mathrm{kg}, \mathrm{p} . \mathrm{o} .)\end{array}$ & $\begin{array}{c}\mathrm{ID}_{50} / \mathrm{ED}_{50} \text { ratio } \\
{[\mathrm{B} / \mathrm{A}]}\end{array}$ \\
\hline HSR-609 & $0.021(0.011-0.042)$ & $(8.3-17)$ & 570 \\
\hline PY-608 & $0.016(0.008-0.033)$ & $0.039(0.028-0.055)$ & 2.4 \\
\hline Cyproheptadine & $0.10(0.053-0.19)$ & $0.16 \quad(0.10-0.25)$ & 1.6 \\
\hline Ketotifen & $0.12(0.054-0.24)$ & $0.24 \quad(0.17-0.33)$ & 2.0 \\
\hline Azelastine & $0.12(0.054-0.24)$ & $0.43 \quad(0.32-0.56)$ & 3.6 \\
\hline Oxatomide & $(1.2-10)$ & $(7.1-21)$ & 4.1 \\
\hline Terfenadine & $0.87 \quad(0.43-1.6)$ & $(91-230)$ & 160 \\
\hline Cetirizine & $0.023(0.012-0.046)$ & $(3.5-6.7)$ & 210 \\
\hline
\end{tabular}

Each test compound was administered orally $1 \mathrm{hr}$ before histamine-induced increase of vascular permeability in mice or ex vivo $\left[{ }^{3} \mathrm{H}\right]$ mepyramine binding to $\mathrm{H}_{1}$-receptors in mouse brain. The $\mathrm{ED}_{50}$ and $\mathrm{ID}_{50}$ values and their $95 \%$ confidence limits $(95 \%$ C.L.) were calculated.

doses of more than $0.03 \mathrm{mg} / \mathrm{kg}$ was statistically significant. The $E D_{50}$ value of HSR -609 was $0.021 \mathrm{mg} / \mathrm{kg}$, and its potency was almost the same as those of PY-608 and cetirizine, but more than those of cyproheptadine, ketotifen, azelastine, oxatomide and terfenadine (Table 2).

Effect on ex vivo $\left[^{3} H\right]$ mepyramine binding to $H_{1}$-receptors in mouse brain

Oral administration of HSR-609 at doses of 10 and $30 \mathrm{mg} / \mathrm{kg}$ produced dose-dependent inhibition of the $\left[{ }^{3} \mathrm{H}\right]$ mepyramine binding to $\mathrm{H}_{1}$-receptors in mouse brain ex vivo. The $\mathrm{ID}_{50}$ value of HSR-609 was $12 \mathrm{mg} / \mathrm{kg}$, and its potency was less than those of PY-608, cyproheptadine, ketotifen, azelastine and cetirizine, but the same as that of oxatomide and more than that of terfenadine. The $\mathrm{ID}_{50}$ value of $\left[{ }^{3} \mathrm{H}\right]$ mepyramine binding to $\mathrm{H}_{1}$-receptors in mouse brain (B) was compared with the $\mathrm{ED}_{50}$ value of histamine-induced vascular permeability in mice (A). The $\mathrm{ID}_{50} / \mathrm{ED}_{50}$ ratio (B/A) of HSR-609 was 570; and its value was much larger than those of PY-608 (2.4), cyproheptadine (1.6), ketotifen (2.0), azelastine (3.6), oxatomide (4.1) and larger than those of terfenadine (160) and cetirizine (210) (Table 2).

Effect on ex vivo [ $\left.{ }^{3} H\right]$ mepyramine binding to $H_{1}$-receptors in the cerebral cortex and lung of guinea pigs

Oral administration of HSR -609 at doses of $0.1-10$ $\mathrm{mg} / \mathrm{kg}$ produced dose-dependent inhibition of the $\left[{ }^{3} \mathbf{H}\right]$ mepyramine binding to $\mathrm{H}_{1}$-receptors in guinea pig lung ex vivo, and the inhibition at doses of more than $0.1 \mathrm{mg} / \mathrm{kg}$ was statistically significant. Oral administration of HSR-
609 at doses of 10 and $100 \mathrm{mg} / \mathrm{kg}$ produced dose-dependent inhibition of the $\left[{ }^{3} \mathrm{H}\right]$ mepyramine binding to $\mathrm{H}_{1}$-receptors in the cerebral cortex of guinea pigs ex vivo, and the inhibition at doses of more than $10 \mathrm{mg} / \mathrm{kg}$ was statistically significant. The minimum inhibitory dose of HSR-609 in the lung was 100 times less than that in the cerebral cortex. The dose ratio of HSR- 609 was much larger than those of PY-608 (10) and ketotifen (1), but the same as that of terfenadine (100) (Fig. 2).

\section{DISCUSSION}

According to our previous basic studies on the relationship between chemical structure and pharmacological activity, zwitter-ionization of classical tricyclic antihistamines by introducing $\mathrm{N}$-alkyl-carboxy groups instead of $N$-alkyl groups results in retention of the $\mathrm{H}_{1}$ receptor antagonistic activity, while greatly reducing other pharmacological activities such as antagonistic activities toward muscarinic, serotonergic and $\alpha_{1}$-adrenergic receptors, affinities for $\alpha_{2}$-adrenergic and dopamine $\mathrm{D}_{2}$ receptors, and inhibitory effects on noradrenaline and serotonin uptakes (1). Our results from the in vitro binding assay also showed that the new zwitter-ionizated amphoteric compound HSR-609 had low affinities for muscarinic and 5- $\mathrm{HT}_{2}$-receptors, but high affinities for $\mathrm{H}_{1^{-}}$ receptors. In contrast, the non-amphoteric basic compound PY-608 displayed high affinities for $\mathrm{H}_{1^{-}}$, muscarinic and 5- $\mathrm{HT}_{2}$-receptors and low selectivity for the $\mathrm{H}_{1^{-}}$receptor in vitro. Therefore, these findings indicate that the amphoteric chemical structure of HSR-609 may play an important role in its high selectivity for the $\mathrm{H}_{1}$-recep- 

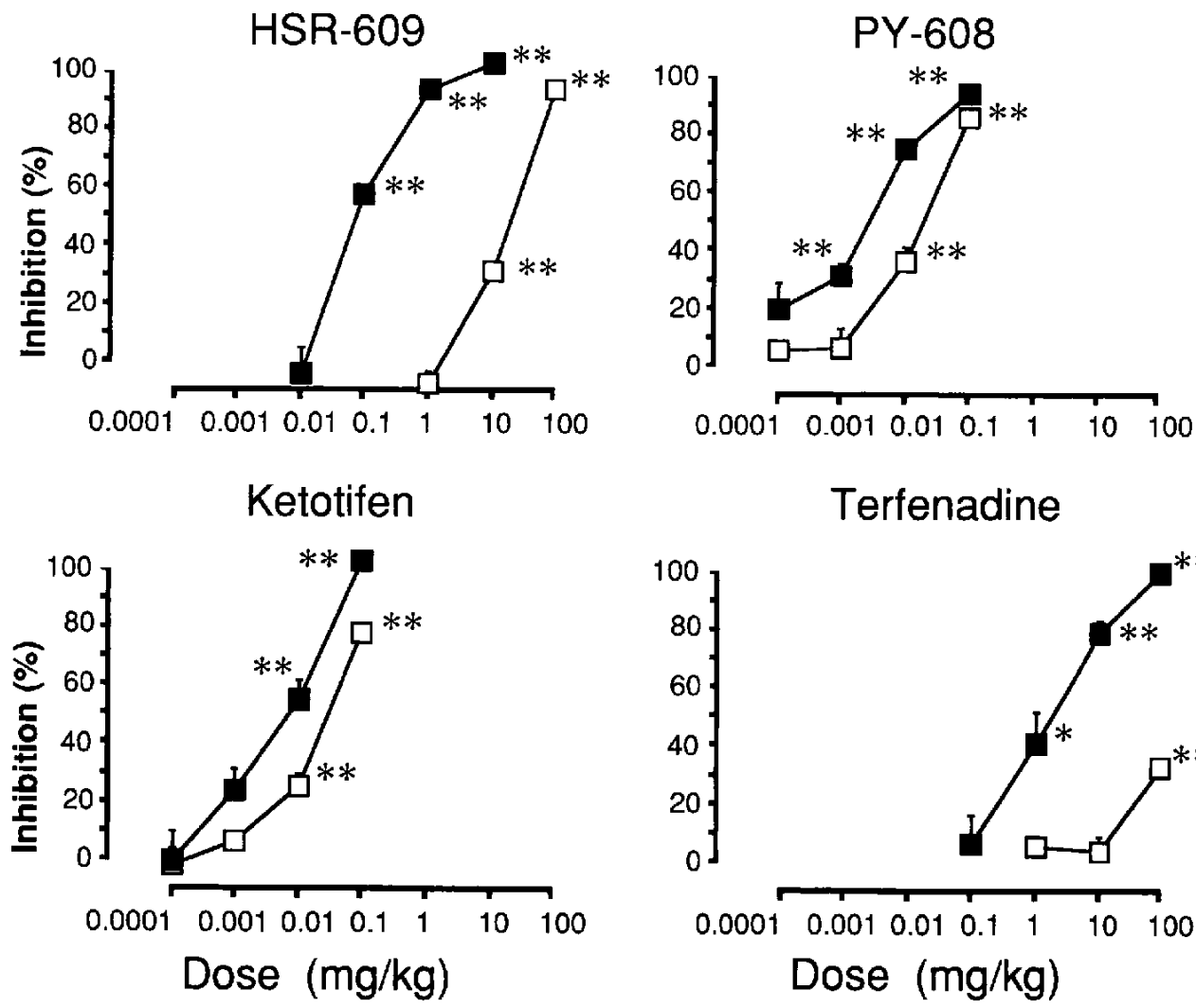

Terfenadine

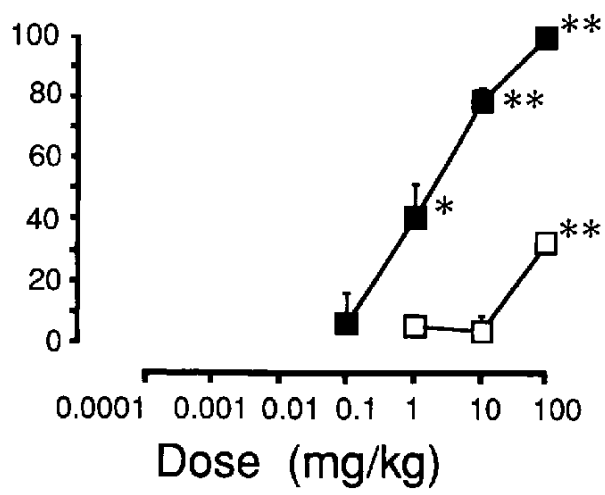

Fig. 2. Inhibitory effects of HSR-609, PY-608, ketotifen and terfenadine on $\left[{ }^{3} \mathrm{H}\right]$ mepyramine binding to $\mathrm{H}_{1}$-receptors in the lung ( $\square$ ) and cerebral cortex $(\square)$ of guinea pigs ex vivo. Each point represents the mean \pm S.E. of 4 animals. ${ }^{*} P<0.05$, ${ }^{* *} \mathrm{P}<0.01$, compared to the vehicle control (Dunnett's multiple comparison test). The specific binding in the vehicle controls for HSR-609, PY-608, ketotifen and terfenadine in the case of the cerebral cortex were $2850 \pm 130,2440 \pm 140,2120 \pm 110$ and $2250 \pm 140(\mathrm{dpm})$; and in the case of lung, they were $1640 \pm 190,1960 \pm 70,1470 \pm 250$ and $1590 \pm 180$ (dpm), respectively.

tor.

Sedative and hypnotic effects in humans have been found with not only antihistamines, but also the muscarinic receptor antagonist scopolamine, and the $5-\mathrm{HT}_{2^{-}}$ receptor antagonist ritanserin $(11,19,20)$. Therefore, it has been suggested that the sedative actions of classical antihistamines may be ascribed to other properties including anticholinergic and antiserotonergic effects as well as antihistaminic effects (11). Our results from the in vitro binding assay also showed that sedative antiallergic agents such as cyproheptadine and oxatomide displayed high affinities not only for $\mathrm{H}_{1}$-receptors, but also for muscarinic and/or 5 - $\mathrm{HT}_{2}$-receptors. These findings indicate that the depressant effects on the CNS of some sedative antiallergic agents may arise from their effects on the muscarinic and/or $5-\mathrm{HT}_{2}$-receptors as well as the $\mathrm{H}_{1}$ receptor. Terfenadine had moderate affinity for $5-\mathrm{HT}_{2-}$ receptors and low selectivity for the $\mathrm{H}_{1}$-receptor in vitro, in agreement with previous reports $(11,21)$. Terfenadine was reported to undergo rapid and extensive biotransformation to a carboxylic acid derivative (active metabolite) and an amino derivative (inactive metabolite) in humans (22), Its effects in vitro are not thought to directly reflect the in vivo effect. On the other hand, HSR- 609 has been found to be hardly metabolized in rats and dogs, and its unchanged form is thought to be an active compound (unpublished data). Therefore, the selective effect of HSR-609 on the $\mathbf{H}_{1}$-receptor in vitro is thought to directly reflect the in vivo effect, and these findings suggest that HSR-609 is unlikely to produce clinical side effects such as sedation and dryness of the mouth, which are due to antimuscarinic and/or antiserotonergic effects.

On the basis of the selectivity of HSR-609 for the $\mathrm{H}_{1}$ receptor in vitro, its ability to penetrate into the CNS was evaluated by the potency ratio between the inhibitory effect on histamine-induced increase of vascular permeability in mice $\left(E_{50}\right)$ and the ex vivo displacement of $\left[{ }^{3} \mathrm{H}\right]$ mepyramine binding to $\mathrm{H}_{1}$-receptors in mouse brain $\left(\mathrm{ID}_{50}\right)$. The $\mathrm{ID}_{50} / \mathrm{ED}_{50}$ ratios of cyproheptadine, ketotifen, azelastine and oxatomide were much smaller than those of terfenadine and cetirizine. Therefore, we checked for obvious differences in the abilities to pen- 
etrate into the CNS in mice between sedative and nonsedative antiallergic agents having antihistaminic activities by using ex vivo displacement of $\left[{ }^{3} \mathrm{H}\right]$ mepyramine binding in comparison to the peripheral antihistaminic effect. The ratio of HSR-609 was much larger than those of sedative antiallergic agents and larger than those of non-sedative antiallergic agents. These results indicate that the ability of HSR- 609 to penetrate into the CNS in mice is much lower than those of sedative antiallergic agents and lower than those of non-sedative antiallergic agents.

Furthermore, the ability of HSR- 609 to penetrate into the CNS in guinea pigs was evaluated by the ex vivo displacement of $\left[{ }^{3} \mathrm{H}\right]$ mepyramine binding to $\mathrm{H}_{1}$-receptors in the cerebral cortex and the lung. HSR-609 displayed potent displacement of the binding in the lung at much lower doses than those in the cerebral cortex. The peripheral tissue selectivity of HSR-609 was higher than that of ketotifen and similar to that of terfenadine. These results indicate that there is little difference in the penetrative ability of a sedative antiallergic agent between the peripheral tissue and the CNS in guinea pigs. However, the ability of HSR-609 and a non-sedative antiallergic agent to penetrate into the CNS was lower than that into the peripheral tissue. Leysen et al. (21) also showed, using ex vivo displacement of $\left[{ }^{3} \mathrm{H}\right]$ mepyramine binding in guinea pigs, that terfenadine seems to have the ability of selective penetration into the lung in comparison to the cerebellum, similar to our resuits. However, according to their results, terfenadine at a dose of $10 \mathrm{mg} / \mathrm{kg}$ showed much more penetration into the cerebellum compared with our findings. This may have been due to differences in strain, sex and tissue of guinea pigs or other experimental conditions. Leysen et al. used the cerebellum of female Pirbright guinea pigs, while we used the cerebral cortex of male Hartley guinea pigs.

The antihistaminic activity of the non-amphoteric basic compound PY-608 on histamine-induced increase of vascular permeability in mice was as potent as that of HSR609. However, the penetrative abilities of PY-608 into the CNS in mice and guinea pigs ex vivo were much higher than those of HSR-609. Therefore, these results indicate that the amphoteric chemical structure of HSR-609 may be an important factor in reducing the penetration into the CNS.

In conclusion, the pharmacological differences between sedative and non-sedative antiallergic agents can be clearly evaluated by determining their abilities to penetrate into the CNS, using ex vivo displacement of $\left[{ }^{3} \mathrm{H}\right]$ mepyramine binding to $\mathbf{H}_{1}$-receptors in the brain and peripheral tissue of mice and guinea pigs. HSR-609 appears to have high selectivity for the $\mathrm{H}_{1}$-receptor, but poor ability to penetrate into the CNS, which may be due to its amphoteric chemical structure. These findings suggest that HSR-609 can be an antiallergic agent having few depressant effects on the CNS such as sedation.

A part of these findings was presented at The 68th Annual Meeting of The Japanese Pharmacological Society in Nagoya (March 25-28, 1995) $\left(\mathrm{P}_{3}-155\right)$ and The 69th Annual Meeting of The Japanese Pharmacological Society in Nagasaki (March 20-23, 1996) (P-131).

\section{Acknowledgments}

The authors would like to thank Dr. K. Yamamoto (The Cell Science Research Foundation, Osaka) for his helpful advice on the manuscript. We also thank Dr. S. Yasuda, Dr. N. Iwasaki, Dr. M. Oshita, Dr. Y. Iwanaga, Dr. T. Hosotani, Mr. N. Ohara, Mrs. K. Kamiyama and Mrs. M. Uno in our laboratories for their helpful suggestions and technical assistance, and Mrs. J. Noguchi for helping with the English editing of the manuscript.

\section{REFERENCES}

1 Muramatsu H, Sawanishi H, Iwasaki N, Kakiuchi M, Ohashi T, Kato $\mathrm{H}$ and Ito $\mathrm{Y}$ : Study on zwitter-ionization of drugs. II: Synthesis and pharmacological activity of some $\mathrm{N}$-[3-(5Hdibenzo[ $a, d]$ cyclohepten-5-ylidene) propyl]- $N$-metylamino- and $N$-[3-(6H-dibenz-[b,e]oxepin-11-ylidene)propyl]- $N$-methylaminoalkanoic acid derivatives and related compounds. Chem Pharm Bull (Tokyo) 41, 1987- 1993 (1993)

2 Iwasaki N, Ohashi T, Musoh K, Nishino H, Kado N, Yasuda S, Kato $\mathrm{H}$ and Ito $\mathrm{Y}$ : Amphoteric drugs. 3: Synthesis and antiallergic activity of 3-[(5,11-dihydro[1]benzoxepino[4,3-b]piperidin-11-ylidene)piperidino]propionic acid derivatives and related compounds. J Med Chem 38, 496-507 (1995)

3 Musoh K, Ohashi T, Takahashi H, Iwanaga $\mathrm{Y}$, Morikawa K, Kato $\mathrm{H}$ and Ito $\mathrm{Y}$ : Pharmacological studies of HSR-609, a novel amphoteric antiallergic agent (1): Effects on various allergic models. Jpn J Pharmacol 67, Supp I, 285P (1995)

4 Lavenstein AF, Dacaney EP, Lasagna L and Van Metre TE: Effect of cyproheptadine on asthmatic children. J Am Med Assoc 16, 912-916 (1962)

5 Quach TT, Duchemin AM, Rose C and Schwartz JC: In vivo occupation of cerebral histamine $\mathrm{H}_{1}$-receptors evaluated with ${ }^{3} \mathrm{H}$-mepyramine may predict sedative properties of psychotropic drugs. Eur J Pharmacol 60, 391-392 (1979)

6 Juniper EF, Cartier A, Trebilcock AL, Frith PA, Dolovich J and Hargreave FE: Effects of oxatomide compared with chlorpheniramine in allergic rhinoconjunctivities. Clin Allergy 11, $61-66$ (1981)

7 McTavish D and Sorkin EM: Azclastine: A review of its pharmacodynamic and pharmacokinetic properties and therapeutic potential. Drugs 38, 778-800 (1989)

8 Campoli-Richards DM, Buckley MMT and Fitton A: Cetirizine: A review of its pharmacological properties and clinical potential in allergic rhinitis, pollen-induced asthma and chronic urticaria. Drugs 40, 762-781 (1990)

9 Estelle $\mathrm{F}$ and Simons $\mathrm{R}: \mathrm{H}_{1}$-receptor antagonists: Comparative tolerability and safety. Drug Safety 10, 350-380 (1994)

10 Rose C, Quach TT, Llorens C and Schwartz JC: Relationship between occupation of cerebral $\mathrm{H}_{1}$-receptors and sedative properties of antihistamines. Arzneimittelforschung 32, 1171-1173 
(1982)

11 Snyder SH and Snowman AM: Receptor effects of cetirizine. Ann Allergy 59, 4-8 (1987)

12 Ahn HS and Barnett A: Selective displacement of $\left[{ }^{3} \mathrm{H}\right]$ mepyramine from peripheral vs. central nervous system receptors by loratadine, a non-sedating antihistamine. Eur J Pharmacol 127, $153-155$ (1986)

13 McPherson GA: Analysis of radioligand binding experiments; A collection of computer programs for the IBM PC. J Pharmacol Methods 14, 213-228 (1985)

14 Cheng YC and Prusoff WH: Relationship between the inhibition constant $\left(\mathrm{K}_{\mathrm{j}}\right)$ and the concentration of inhibitor which causes 50 percent inhibition $\left(I_{50}\right)$ of an enzymatic reaction. Biochem Pharmacol 22, 3099-3108 (1973)

15 Oshita $\mathrm{M}$, Ohashi $\mathrm{T}$, Morikawa $\mathrm{K}$, Kato $\mathrm{H}$, Ito $\mathrm{Y}$ and Muramatsu I: Studies on the affinity and selectivity of tiquizium bromide (HSR-902), a novel spasmolytic agent, for muscarinic receptors. Jpn J Pharmacol 44, 222-224 (1987)

16 Leysen JE, Niemegreers JE, Van Nueten JM and Laduron PM: $\left[{ }^{3} \mathrm{H}\right]$ Ketanserin (R41468), a selective ${ }^{3} \mathrm{H}$-ligand for serotonin ${ }_{2}$ receptor binding sites. Mol Pharmacol 21, 301-314 (1982)

17 Katayama S, Shionoya $\mathrm{H}$ and Ohtake S: A new method for extraction of extravasated dye in the skin and the influence of fasting stress on passive cutaneous anaphylaxis in guinea pigs and rats. Microbiol Immunol 22, 89-101 (1978)

18 Tallarida RJ and Murray RB: Graded dose-response. In Manual of Pharmacologic Calculations with Computer Programs, Vol 2, pp 16-31, Springer-Verlag, New York (1987)

19 Brown JH and Taylor P: Muscarinic receptor agonists and antagonists. In The Pharmacological Basis of Therapeutics, 9th ed, Edited by Hardman JG, Limbird LE, Molinoff PB, Ruddon RW and Gilman AG, pp 141-160, McGraw-Hill Co, New York (1996)

20 Idizikowski C, Mills FJ and James RJ: A dose-response study examining the effects of ritanserin on human slow wave sleep. Br J Clin Pharmacol 31, 193-196 (1991)

21 Leysen JE, Gommeren W, Janssen PFM and Janssen PAJ: Comparative study of central and peripheral histamine- $\mathrm{H}_{1}$ receptor binding in vitro and ex vivo of non-sedating antihistamines and of noberastine, a new agent. Drug Dev Res 22, $165-178$ (1991)

22 Desager JP and Horsmans Y: Pharmacokinetic-pharmacodynamic relationships of $\mathrm{H}_{\mathrm{L}}$-antihistamines. Clin Pharmacokinet 28, 419-432 (1995) 